\title{
In situ formed tert-butyl hypoiodite as an efficient oxidant for rapid, room temperature, metal-free dehydrogenation of Biginelli 3,4- dihydropyrimidin-2(1H)-ones under basic conditions
}

\author{
Danijela Lesjak Kolarović, ${ }^{\mathrm{a}}$ Vladimir Vinković, ${ }^{\mathrm{b}}$ and Mladen Litvić*a \\ ${ }^{a}$ BELUPO Pharmaceuticals, Inc., R\&D, Danica 5, 48000 Koprivnica, Croatia \\ ${ }^{b}$ Institute Ruđer Bošković, Bijenička c. 54, 10002 Zagreb, Croatia \\ E-mail: danijela.lesjakkolarovic@,belupo.hr,mladen.litvic@belupo.hr
}

DOI: http://dx.doi.org/10.3998/ark.5550190.p009.562

\begin{abstract}
A mild, highly efficient synthetic method was developed for the dehydrogenation of 3,4dihydropyrimidin-2(1H)-ones employing in situ formed tert-butyl hypoiodite under basic conditions. The oxidant was prepared by the reaction of molecular iodine and potassium tertbutoxide. The reaction was carried out in dry tetrahydrofuran at room temperature and high purity products were isolated in high yields after simple work-up. The reaction times (3-10 min.) indicated the new method is superior in comparion to other literature oxidants employed under classical conditions or microwave promoted reactions. Two plausible mechanisms of dehydrogenation were proposed and the active species tert-butyl hypoiodite was characterized by $\mathrm{UV} / \mathrm{V}$ is spectroscopy method.
\end{abstract}

Keywords: Dehydrogenation, 3,4-dihydropyrimidin-2(1H)-ones, iodine, tert-butyl hypoiodite

\section{Introduction}

3,4-Dihydropyrimidin-2(1H)-ones (3,4-DHPM) are molecules that represent a diazaheterocyclic system with excellent pharmacological efficiency ${ }^{1}$ and as such have become significant synthetic objects in organic and medicinal chemistry. ${ }^{2}$ These compounds are also known as Biginelli compounds, after the Italian chemist Pietro Biginelli, who first reported the useful multicomponent acid-catalyzed cyclocondensation reaction of an aldehyde, a $\beta$-ketoester and urea $^{3}$ some 120 years ago. The variation of all three starting components led to a high molecular diversity of products ${ }^{4}$ that may exhibit properties such as antiviral, antibacterial, antifungal, anticancer, antitubercular and antihypertensive properties, or act as calcium channel blockers. ${ }^{2}$

The heterocyclic 3,4-DHPM core has an intrinsic reactivity that allows many chemical transformations, such as oxidation (dehydrogenation/aromatization). ${ }^{2}$ This type of transformation 
has become one of the most popular reactions of 3,4-dihydropyrimidin-2(1H)-ones in the past two decades. Namely, the most accepted metabolic pathway of 3,4-DHPM drugs is in vivo oxidative dehydrogenation, which occurs in the liver. ${ }^{5}$ Unfortunately, most developed methods for the conversion of dihydropyrimidinones to their oxidized derivatives by oxidative dehydrogenation are far from in vivo physiological conditions. ${ }^{6}$ However, the study of those methods is important to facilitate an understanding of the metabolism of DHPM drugs. On the other hand, research on thermal and photochemical oxidation methods for organic molecules, especially those with pharmaceutical properties, is important to understand their stability and photochemical behavior. ${ }^{7,8}$ Finally, dehydrogenation of 3,4-DHPMs is a good way to obtain new heterocyclic, potentially biologically active molecules that contain the pharmacologically important pyrimidin-2(1H)-one scaffold.

The oxidative dehydrogenation of 3,4-DHPMs was found to be more difficult than that of Hantzsch 1,4-dihydropyridine due to their stable structure ${ }^{9}$ and the sensitivity of the methyl group at the C-6 position. ${ }^{10,11}$ Nevertheless, over the past two decades, different reagents and methods have been used, more or less successfully, for this type of reaction. Some are: tert$\mathrm{BHP} / \mathrm{CuCl}_{2},{ }^{12} \quad \mathrm{CAN} / \mathrm{NaHCO}_{3},{ }^{13} \mathrm{Co}\left(\mathrm{NO}_{3}\right)_{2} / \mathrm{K}_{2} \mathrm{~S}_{2} \mathrm{O}_{8},{ }^{11}$ tert-BHP/PhI(OAc) $)_{2},{ }^{14} \mathrm{PCC},{ }^{15}$ sonothermal oxidation $/ \mathrm{K}_{2} \mathrm{~S}_{2} \mathrm{O}_{8},{ }^{16} \mathrm{O}_{2}$ /activated carbon, ${ }^{17}$ microwave-assisted oxidation, ${ }^{18} \mathrm{NO}^{+} \mathrm{BF}_{4}{ }^{-19}$ photocatalytic oxidation/ $/ \mathrm{TiO}_{2},{ }^{20,21}$ thermal oxidation $/ \mathrm{K}_{2} \mathrm{~S}_{2} \mathrm{O}_{8},{ }^{22} \mathrm{UV}$ light induced oxidation/Ar, ${ }^{7,8}$ ultrasound-assisted oxidation $/ \mathrm{K}_{2} \mathrm{~S}_{2} \mathrm{O}_{8},{ }^{23}$ aerobic oxidative dehydrogenation/NHPI/Co ${ }^{\text {II }}{ }^{24}$ using $\mathrm{Ca}(\mathrm{OCl})_{2}$ in aqueous media oxidation, ${ }^{6}$ photochemical oxidation using $\operatorname{Re}(\mathrm{I})$ complex, ${ }^{25}$ $\mathrm{CAN} / \mathrm{HCl}^{26}$ microwave-assisted oxidation $/ \mathrm{I}_{2},{ }^{27}$ light-induced free radical oxidation, ${ }^{28}$ dehydrogenation with 1,4-bis(triphenylphosphonium)-2-butene peroxodisulfate ${ }^{29}$ and others. ${ }^{30-33}$ However, despite best efforts, none of these methods have been found to be ideal with respect to prolonged reaction time, low yield, use of toxic reagents, complicated product isolation, etc. Therefore, there is still a need to seek out new and more efficient 3,4-DHPM dehydrogenation methods.

\section{Results and Discussion}

Initial studies were conducted on the simple model 3,4-DHPM 1, employing different oxidants such as inorganic salts under a number of reaction conditions that are usually effective for the dehydrogenation of Hantzsch 1,4-DHPs, in order to determine the general type of oxidant and the reaction condition convenient for this type of reaction. The following reagents were tested under different reaction conditions: $\mathrm{V}_{2} \mathrm{O}_{5} / \mathrm{K}_{2} \mathrm{CO}_{3}$ in acetonitrile, $\mathrm{Bi}\left(\mathrm{NO}_{3}\right)_{3} \times 5 \mathrm{H}_{2} \mathrm{O}$ in acetic acid, $\mathrm{VOCl}_{3}$ in dichloromethane, $\mathrm{SeO}_{2}$ in acetic acid, $\mathrm{MnO}_{2}$ in acetic acid, $\mathrm{SnCl}_{4}$ in acetonitrile, $\mathrm{SbCl}_{5}$ in toluene, $\mathrm{Mn}(\mathrm{OEt})_{4}$ in acetic acid, $\mathrm{NaClO}_{2}$ in acetic acid, $\mathrm{NaNO}_{2}$ in acetic acid, $\mathrm{NaIO}_{4}$ in acetic acid, $\mathrm{ZrCl}_{4}$ in toluene/acetonitrile/acetic acid, $\mathrm{KBrO}_{3}$ in acetic acid/trifluoroacetic acid, $\mathrm{Pb}(\mathrm{OAc})_{4}$ in acetic acid, $\mathrm{K}_{2} \mathrm{~S}_{2} \mathrm{O}_{8} / \mathrm{I}_{2}$ in acetic acid, $\mathrm{FeCl}_{3} \times 6 \mathrm{H}_{2} \mathrm{O}$ in acetonitrile/acetic acid, $\mathrm{FeCl}_{3}$ in acetonitrile/acetic acid, $\mathrm{FeCl}_{3}$ /Hünig's base in acetonitrile, iron(III) phtalocyanine chloride in 
acetic acid and others. Surprisingly, none of these reagents gave a satisfactory result due to low chemoselectivity, low conversion, decomposition of starting material, or no reaction at all. Based on these negative results, we concluded that acid conditions do not support the aromatization of the model 3,4-DHPM 1.

Further studies were focused on basic reaction conditions and molecular iodine as the oxidant. According to the literature, molecular iodine is used as a selective oxidant for many organic transformations. Previously, we utilized molecular iodine as an effective catalyst in a new method for acetoxylation of the 1,4-benzodiazepine ring and applied it to kilogram-scale production of lorazepam and oxazepam. ${ }^{34}$ Under normal conditions or under ultrasound irradiation, molecular iodine selectively oxidizes 1,4 -DHPs at elevated temperatures, ${ }^{35}$ while in combination with the urea-hydrogen peroxide adduct (UHP), the same reaction is performed at room temperature. ${ }^{36}$ In the case of 3,4-DHPMs, the UHP itself and in combination with molecular iodine, under different reaction conditions, did not afford a product with a satisfactory result.

Table 1. Dehydrogenation of 3,4-DHPM 1 with molecular iodine (1.1 equiv) under different reaction conditions at room temperature<smiles>COC(=O)C1=C(C(C)C)NC(=O)NC1c1ccc(F)cc1</smiles>

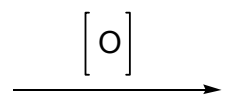<smiles>COC(=O)c1c(-c2ccc(F)cc2)nc(=O)[nH]c1C(C)C</smiles>

\begin{tabular}{ccccc}
\hline Entry & Base $^{\mathbf{a}}$ & Solvent & $\mathbf{t ~ ( m i n . ) ~}$ & Yield (\%) $^{\mathbf{b}}$ \\
\hline 1 & tert-BuOK & toluene & 15 & 97 \\
2 & tert $-\mathrm{BuOK}$ & $\mathrm{THF}$ & 2 & 96 \\
3 & tert $\mathrm{BuOK}$ & tert $-\mathrm{BuOH}$ & 10 & 96 \\
4 & $\mathrm{NaH}$ & $\mathrm{THF}$ & 15 & 95 \\
5 & $\mathrm{NaOH}$ & $\mathrm{MeOH}$ & 10 & 60 \\
6 & $\mathrm{KOH}$ & $\mathrm{MeOH}$ & 10 & 59 \\
7 & $\mathrm{~K}_{2} \mathrm{CO}$ & $\mathrm{MeOH}$ & 10 & 31 \\
8 & EtN $(i-\mathrm{Pr})_{2}$ & $\mathrm{CH}_{2} \mathrm{Cl}$ & 120 & $-{ }^{\mathrm{c}}$ \\
9 & tert $-\mathrm{BuOK}$ & tert-BuOAc & 150 & $-{ }^{\mathrm{c}}$ \\
\hline
\end{tabular}

${ }^{\mathrm{a}}$ Base (3 equiv). ${ }^{\mathrm{b}}$ Isolated yield.

${ }^{\mathrm{c}}$ Low chemoselectivity and low yield $(<10 \%)$. 
Surprisingly, the reaction of model compound $\mathbf{1}$ with a stoichiometric amount of molecular iodine in the presence of a strong base such as potassium tert-butoxide, in THF as the solvent, at room temperature, selectively afforded product $\mathbf{2}$ in several minutes. Encouraged by this result, further studies were focused on finding the best combination of base/solvent for the reaction performed at room temperature. The results presented in Table 1 indicated excellent conversion in short reaction times with the use of potassium tert-butoxide (tert-BuOK) in toluene (Entry 1), dry tetrahydrofuran (THF, Entry 2) or tert-butanol (tert-BuOH, Entry 3). Due to the highest reaction speed and isolated yield ( 2 minutes, 96\%), the combination potassium tert-butoxide/dry THF was selected for further study. The same reaction, using tert-butanol or toluene as a solvent, also gave excellent yields (96\% and 97\%), though these reactions required a longer reaction time, likely due to the lower solubility of base in these solvents, Table $2 .{ }^{37}$ Interestingly, by employing sodium hydride $(\mathrm{NaH})$ as a base in THF (Entry 4) as a solvent, a high yield was achieved (95\%) in only 15 minutes, though product isolation was challenging due to the presence of mineral oil in sodium hydride. Other bases were inefficient (Table 1, Entries 5-9) and hence not tested further.

Table 2. Solubility of potassium tert-butoxide in different solvents

\begin{tabular}{ccc}
\hline Entry & Solvent & Solubility $^{\text {a }}$ \\
\hline 1 & THF & $25 \mathrm{~g} / 100 \mathrm{ml}$ \\
2 & tert -BuOH & $18 \mathrm{~g} / 100 \mathrm{ml}$ \\
3 & toluene & $2 \mathrm{~g} / 100 \mathrm{ml}$ \\
\hline
\end{tabular}

${ }^{\mathrm{a}}$ Solubility at $20^{\circ} \mathrm{C}$.

Further optimization of the reaction was carried out in order to find the optimal amount of oxidant, molecular iodine (Table 3 ). According to the obtained results, a 1.1 equivalent of $\mathrm{I}_{2}$ (Table 3, Entry 4) was found to be the optimal amount due to the complete conversion of the reaction, high yield (96\%) and short reaction time of just 3 minutes. At lower quantities of iodine (Table 3, Entries 1-3), the conversions were not completed.

In the next step, our aim was to define the optimal amount of base in the reaction. According to the results presented in Table 4, a 2.8 equivalent of base (Entry 6) was optimal, with no loss of reaction speed, conversion and yield. An increased amount of base did not improve the reaction, while lower amounts did not afford a product in satisfactory results (lower yields and higher reaction times).

In order to explore the scope and limitations of this new oxidation method, employing molecular iodine under basic conditions, we tested it on a series of substituted 3,4-DHPMs with a variety of substituents at all positions of the 3,4-DHPM ring. Under optimized reaction conditions with 1.1 equivalent of molecular iodine and 2.8 equivalent of potassium tert-butoxide in dry THF at room temperature, dehydrogenation of differently substituted 3,4-DHPMs was carried out. 
Table 3. Dehydrogenation of 3,4-DHPM 1 with different amounts of molecular iodine in the presence of potassium tert-butoxide ( 3 equiv)

\begin{tabular}{ccc}
\hline Entry & $\mathbf{I}_{\mathbf{2}}$ (equiv) & $\begin{array}{c}\text { Yield } \\
\mathbf{( \% )}^{\mathbf{a}, \mathbf{b}}\end{array}$ \\
\hline 1 & 0.95 & 91 \\
2 & 1 & 94 \\
3 & 1.05 & 95 \\
4 & 1.1 & 96 \\
5 & 2 & 97 \\
6 & 3 & 97 \\
\hline
\end{tabular}

${ }^{\mathrm{a}}$ Isolated yield.

${ }^{b}$ Reactions were carried out at room temperature, in THF, during 3 minutes.

Table 4. Dehydrogenation of 3,4-DHPM 1 with molecular iodine (1.1 equiv) in the presence of different amounts of potassium tert-butoxide

\begin{tabular}{ccc}
\hline Entry & tert-BuOK (equiv) & Yield (\%) $^{\mathbf{a}, \mathbf{b}}$ \\
\hline 1 & 1 & 50 \\
2 & 2 & 84 \\
3 & 2.5 & 93 \\
4 & 2.6 & 94 \\
5 & 2.7 & 94 \\
6 & 2.8 & 96 \\
7 & 2.9 & 96 \\
8 & 3 & 96 \\
\hline
\end{tabular}

${ }^{\mathrm{a}}$ Isolated yield.

${ }^{b}$ Reactions were carried out at room temperature, in THF, during 3 minutes.

The results presented in Table 5 show that new method is generally applicable for the oxidation of different 3,4-DHPMs. The main characteristics of the reaction are excellent selectivity, high speed, good to excellent yields and high product purity. The reactions were completed in 3-10 minutes, making this system faster than to other known literature methods for the oxidation of 3,4-DHPMs employing classical reaction conditions. The reaction speed of the presented method is comparable to microwave promoted reactions which, in turn, require high temperatures. Product yields ranged from 68-96\%, except for compound 5 (Table 5, Entry 4), due to the presence of the ortho-nitro group on the aromatic ring, which gave product at a yield of 55\%. Both electron-withdrawing (Table 5, Entries 4-6) and electron-donating substituents (Table 5, Entries 7, 8, 15-17, 24) on the aromatic ring were well tolerated and had no considerable influence on the reaction rate. The oxidation of all sterically constrained derivatives 
with an isopropyl group instead of a methyl group at position 6 of the 3,4-DHPM ring conveyed product in slightly higher yields, due to its lower acidity compared to the methyl group.

Table 5. Dehydrogenation of substituted 3,4-DHPMs with molecular iodine (1.1 equiv) in the presence of potassium tert-butoxide ( 2.8 equiv) at room temperature

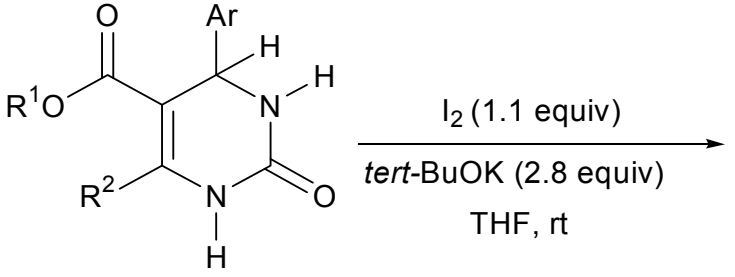

1, 3-25<smiles>[R20]C(=O)c1c(Br)nc(=O)[nH]c1[R]</smiles>

2, 26-48

\begin{tabular}{|c|c|c|c|c|c|c|c|}
\hline Entry & $\begin{array}{c}\text { 3,4- } \\
\text { DHPM }\end{array}$ & Ar & $\mathbf{R}^{1} ; \mathbf{R}^{2}$ & Product & $\begin{array}{c}T \\
\text { (min.) }\end{array}$ & $\begin{array}{l}\text { Yield } \\
(\%)^{\mathrm{a}}\end{array}$ & $\begin{array}{l}\text { Mp } \\
\left({ }^{\circ} \mathrm{C}\right)\end{array}$ \\
\hline 1 & 1 & $p-\mathrm{FC}_{6} \mathrm{H}_{4}$ & $\mathrm{CH}_{3} ; \mathrm{CH}\left(\mathrm{CH}_{3}\right)_{2}$ & 2 & 3 & 96 & $\begin{array}{c}\text { 196-197, (lit. mp } \\
\text { not reported }^{12} \text { ) }\end{array}$ \\
\hline 2 & 3 & $\mathrm{C}_{6} \mathrm{H}_{5}$ & $\mathrm{CH}_{3} ; \mathrm{CH}_{3}$ & 26 & 5 & 74 & $\begin{array}{c}192-194,(195- \\
197)^{15}\end{array}$ \\
\hline 3 & 4 & $p-\mathrm{ClC}_{6} \mathrm{H}_{4}$ & $\mathrm{CH}_{3} ; \mathrm{CH}_{3}$ & 27 & 5 & 94 & $\begin{array}{c}\text { 176-177, (lit. mp } \\
\text { not reported }^{12} \text { ) }\end{array}$ \\
\hline 4 & 5 & $o-\mathrm{NO}_{2} \mathrm{C}_{6} \mathrm{H}_{4}$ & $\mathrm{CH}_{3} ; \mathrm{CH}_{3}$ & 28 & 3 & 55 & $235-236$ \\
\hline 5 & 6 & $m-\mathrm{NO}_{2} \mathrm{C}_{6} \mathrm{H}_{4}$ & $\mathrm{CH}_{3} ; \mathrm{CH}_{3}$ & $29^{c}$ & $5^{\mathrm{b}}$ & 74 & $201-203$ \\
\hline 6 & 7 & $p-\mathrm{NO}_{2} \mathrm{C}_{6} \mathrm{H}_{4}$ & $\mathrm{CH}_{3} ; \mathrm{CH}_{3}$ & 30 & 3 & 71 & $230-231$ \\
\hline 7 & 8 & $p-\mathrm{CH}_{3} \mathrm{C}_{6} \mathrm{H}_{4}$ & $\mathrm{CH}_{3} ; \mathrm{CH}_{3}$ & 31 & 5 & 72 & $\begin{array}{l}\text { 191-192, (lit. mp } \\
\text { not reported }^{12} \text { ) }\end{array}$ \\
\hline 8 & 9 & $p-\mathrm{CH}_{3} \mathrm{OC}_{6} \mathrm{H}_{4}$ & $\mathrm{CH}_{3} ; \mathrm{CH}_{3}$ & 32 & 5 & 72 & $\begin{array}{c}178-180,(180- \\
181)^{13}\end{array}$ \\
\hline 9 & 10 & 1-naphthyl & $\mathrm{CH}_{3} ; \mathrm{CH}_{3}$ & $33^{\mathrm{c}}$ & 10 & 74 & $173-174$ \\
\hline 10 & 11 & $\mathrm{C}_{6} \mathrm{H}_{5}$ & $\mathrm{CH}_{3} ; \mathrm{CH}\left(\mathrm{CH}_{3}\right)_{2}$ & 34 & 5 & 71 & $\begin{array}{l}\text { 189-191, (lit. mp } \\
\text { not reported }^{12} \text { ) }\end{array}$ \\
\hline 11 & 12 & $o-\mathrm{ClC}_{6} \mathrm{H}_{4}$ & $\mathrm{CH}_{3} ; \mathrm{CH}\left(\mathrm{CH}_{3}\right)_{2}$ & 35 & 5 & 78 & $173-174$ \\
\hline 12 & 13 & $m-\mathrm{ClC}_{6} \mathrm{H}_{4}$ & $\mathrm{CH}_{3} ; \mathrm{CH}\left(\mathrm{CH}_{3}\right)_{2}$ & 36 & 5 & 77 & $190-192$ \\
\hline 13 & 14 & $p-\mathrm{ClC}_{6} \mathrm{H}_{4}$ & $\mathrm{CH}_{3} ; \mathrm{CH}\left(\mathrm{CH}_{3}\right)_{2}$ & 37 & 5 & 92 & $210-211$ \\
\hline 14 & 15 & $o-\mathrm{NO}_{2} \mathrm{C}_{6} \mathrm{H}_{4}$ & $\mathrm{CH}_{3} ; \mathrm{CH}\left(\mathrm{CH}_{3}\right)_{2}$ & 38 & 5 & 78 & $238-239$ \\
\hline 15 & 16 & $2,4-\left(\mathrm{CH}_{3}\right)_{2} \mathrm{C}_{6} \mathrm{H}_{3}$ & $\mathrm{CH}_{3} ; \mathrm{CH}\left(\mathrm{CH}_{3}\right)_{2}$ & 39 & 5 & 68 & $215-216$ \\
\hline 16 & 17 & $p-\mathrm{CH}_{3} \mathrm{C}_{6} \mathrm{H}_{4}$ & $\mathrm{CH}_{3} ; \mathrm{CH}\left(\mathrm{CH}_{3}\right)_{2}$ & 40 & 5 & 70 & $194-196$ \\
\hline 17 & 18 & $p-\mathrm{CH}_{3} \mathrm{OC}_{6} \mathrm{H}_{4}$ & $\mathrm{CH}_{3} ; \mathrm{CH}\left(\mathrm{CH}_{3}\right)_{2}$ & 41 & 5 & 91 & $226-228$ \\
\hline 18 & 19 & $\mathrm{C}_{6} \mathrm{H}_{5}$ & $\mathrm{CH}_{2} \mathrm{CH}_{3} ; \mathrm{CH}_{3}$ & $42^{\mathrm{c}}$ & 10 & 70 & $\begin{array}{c}130-131, \\
(130-132)^{7,16,22}\end{array}$ \\
\hline 19 & 20 & $\mathrm{C}_{6} \mathrm{H}_{5}$ & $\mathrm{CH}\left(\mathrm{CH}_{3}\right)_{2} ; \mathrm{CH}_{3}$ & 43 & 10 & 86 & $191-192$ \\
\hline 20 & 21 & $\mathrm{C}_{6} \mathrm{H}_{5}$ & $\begin{array}{c}\mathrm{CH}_{2} \mathrm{CH}\left(\mathrm{CH}_{3}\right)_{2} ; \\
\mathrm{CH}_{3}\end{array}$ & $44^{\mathrm{c}}$ & 5 & 78 & $151-152$ \\
\hline 21 & 22 & $\mathrm{C}_{6} \mathrm{H}_{5}$ & $\mathrm{CH}_{2} \mathrm{C}_{6} \mathrm{H}_{5} ; \mathrm{CH}_{3}$ & $45^{c}$ & 5 & 77 & $138-140$ \\
\hline 22 & 23 & 2-naphthyl & $\mathrm{CH}_{2} \mathrm{CH}_{3} ; \mathrm{CH}_{3}$ & $46^{\mathrm{c}}$ & 5 & 72 & $83-85$ \\
\hline 23 & 24 & 1-naphthyl & $\mathrm{CH}_{3} ; \mathrm{CH}\left(\mathrm{CH}_{3}\right)_{2}$ & 47 & 5 & 73 & $188-190$ \\
\hline 24 & 25 & $o-\mathrm{CH}_{3} \mathrm{OC}_{6} \mathrm{H}_{4}$ & $\mathrm{CH}_{3} ; \mathrm{CH}\left(\mathrm{CH}_{3}\right)_{2}$ & 48 & 5 & 94 & $169-171$ \\
\hline
\end{tabular}

${ }^{\mathrm{a}}$ Isolated yield. ${ }^{\mathrm{b}}$ Reaction with tert-BuOK (3 equiv). ${ }^{\mathrm{c}}$ Purification by column chromatography. 
The ${ }^{1} \mathrm{H}$ NMR spectrum of products showed peaks of all protons present in the molecule. However, certain quaternary carbons of dehydrogenated products in the ${ }^{13} \mathrm{C}$ NMR spectrum were missing. This effect is well known in the literature for this type of compound. ${ }^{12,13,15,24}$ Shanmugam et al. ${ }^{13}$ provided the explanation that this phenomenon was caused by the tautomerization of $\mathrm{N} 1-\mathrm{H}$ to $\mathrm{N} 3$ in a solution of $N(1)$-alkyl unsubstituted dehydrogenated product. In the case of the ${ }^{13} \mathrm{C}$ NMR spectrum of $N(1)$-alkyl substituted derivatives, which have no tautomerization in solution, all peaks are present.

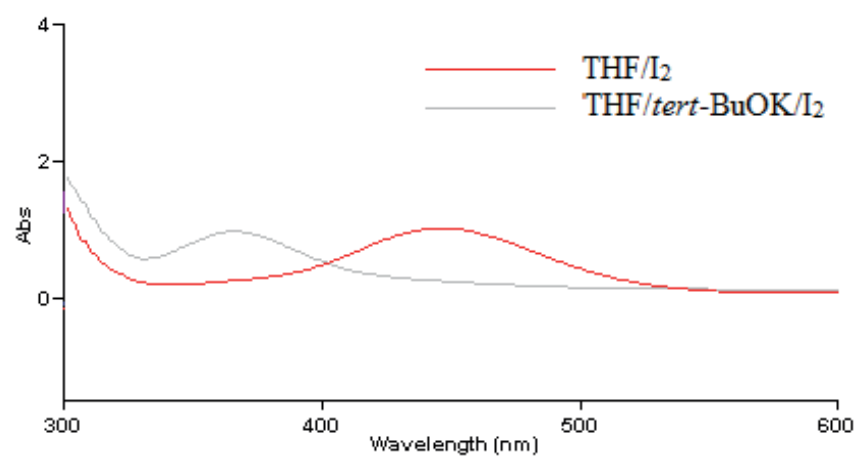

Figure 1. UV/Vis spectra of molecular iodine in THF and the mixture of potassium tert-butoxide and molecular iodine in THF.

In order to determine the reason for the high reaction speed, further studies were performed to clarify the reaction mechanism and determine which oxidation species are formed in the reaction. Even during preliminary studies, a loss of colorization was observed during the mixing of molecular iodine and the base, suggesting the formation of a new, highly reactive species that is capable of oxidizing stable 3,4-DHPMs at room temperature. According to the UV/Vis spectra of the THF solution of molecular iodine, which shows maximum absorbance at $460 \mathrm{~nm}$, and the mixture of potassium tert-butoxide and molecular iodine, with maximum absorbance at $370 \mathrm{~nm}$, it was clear that the maximum absorbance is shifted from the visible area to the UV area of the spectrum (Figure 1). This spectral change is due to the formation of tert-butyl hypoiodite (tert$\mathrm{BuOI}$ ) from molecular iodine and the base, according to the equation.

$$
\mathrm{I}_{2}+\text { tert-BuOK } \longrightarrow \text { tert-BuOI }+\mathrm{KI}
$$

Tert-butyl hypoiodite and other organic hypoiodites have been used in many organic transformations. ${ }^{38}$ For example, Barton used this species to prepare $N$-iodoamides ${ }^{39}$ and to decarboxylate carboxylic acids. ${ }^{40}$ Other authors have used it in the preparation of esters from carboxylic acids and alkyl iodides, ${ }^{41}$ and in the iodination of aromatics with strong electron donor substituents. The usual literature method for the preparation of tert-butyl hypoiodite is the reaction of tert-butyl hypochlorite with either molecular iodine or metal iodides, or by the reaction of potassium tert-butoxide with molecular iodine. According to Tanner et al., ${ }^{38}$ such 
obtained species differ due to their high reactivity and low stability. According to the literature, tert-butyl hypoiodite obtained by the reaction of potassium tert-butoxide and molecular iodine is seldom used in organic synthesis in comparison to reagents prepared by other methods. Moreover, based on Tanner's results, ${ }^{38}$ tert-butyl hypoiodite contained $10 \%$ free iodine, and testing was only performed in carbon tetrachloride as the solvent. In our method, tert-butyl hypoiodite was prepared in dry THF with excess potassium tert-butoxide to allow complete consumption of molecular iodine, which was observed as a rapid color change. Based on this data, tert-butyl hypoiodite prepared by our method was unique in comparison to literature data and was characterized by maximum absorption at $370 \mathrm{~nm}$ (Figure 1).

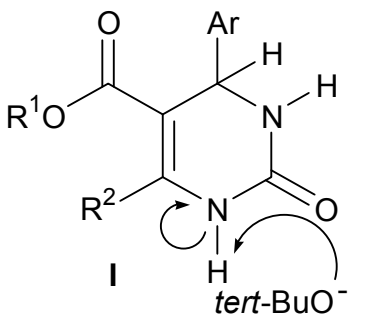

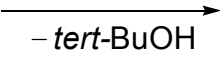<smiles>[R20]C(=O)C1=C([R])N=C(CCI)C([Al])N1N</smiles><smiles>[R20]C(=O)c1c([Al])nc(=O)[nH]c1[R2]</smiles>

IV

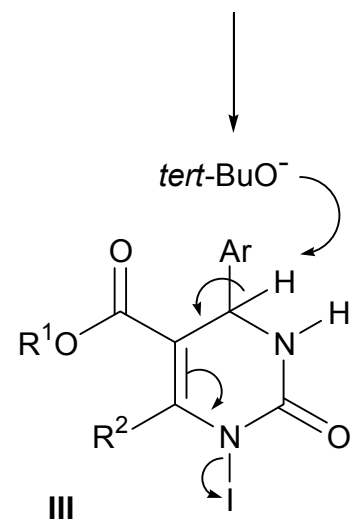

Scheme 1. Possible mechanism of 3,4-DHPM dehydrogenation via base catalysed substitution and elimination.

We proposed two plausible mechanisms of 3,4-DHPMs dehydrogenation employing our method. Strong anhydrous basic conditions of reaction facilitates mechanism presented in Scheme 1. In the first step, the deprotonation of N1-H in I occurs, rather than the deprotonation of N3-H, due to the presence of conjugated enamino ester moiety. The thus formed N1-anion II further reacts with in situ formed tert-butyl hypoiodite to give an $\mathrm{N}$-iodo derivative III. By deprotonation of the $\mathrm{C} 4$ hydrogen with the tert-butoxy anion, and subsequent elimination of the iodide anion and tert-butanol, product IV is formed. 


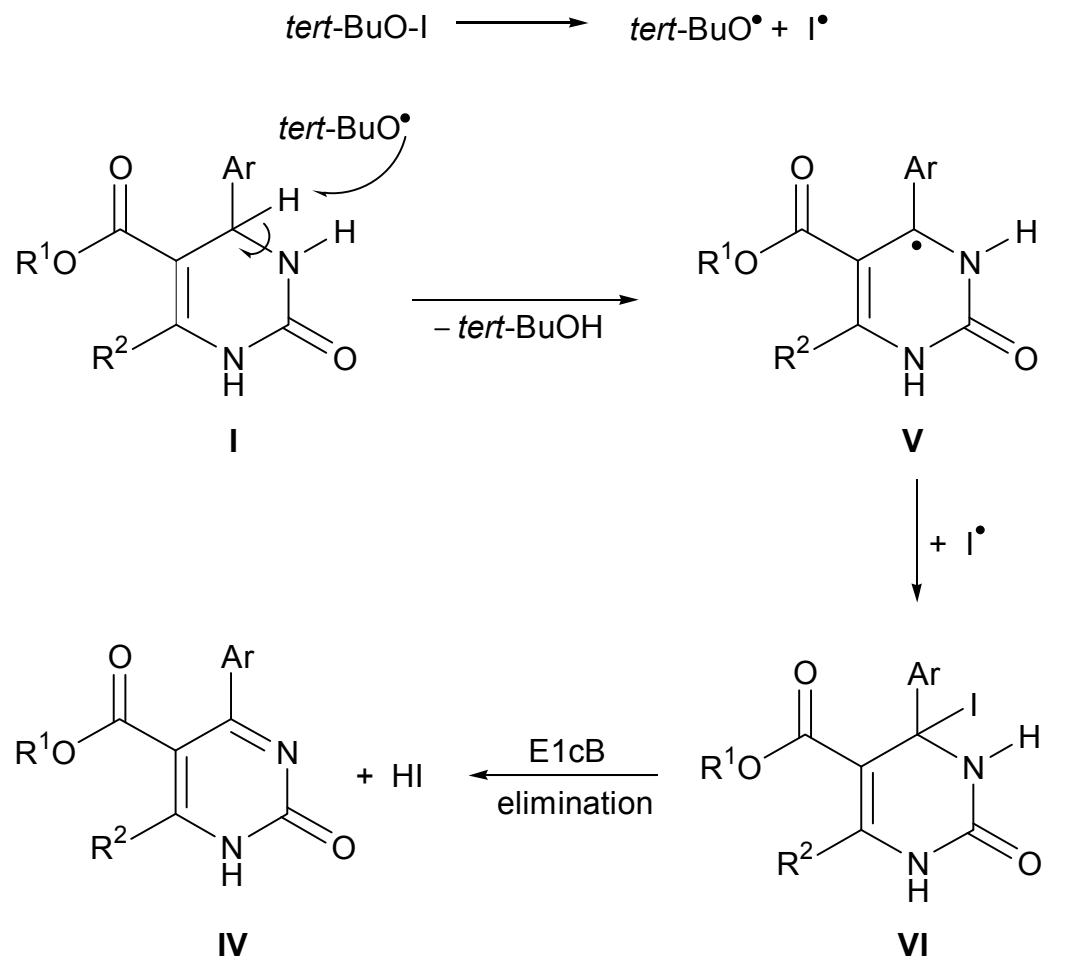

Scheme 2. Radical mechanism of 3,4-DHPM dehydrogenation.

Due to the fact that tert-butyl hypoiodite as well as other organic hypoiodites easily undergo homolytic cleavage ${ }^{42,43}$ to produce tert-butoxy and iodine radicals, radical mechanism was also proposed (Scheme 2). In a first step tert-butoxy radical abstracts hydrogen from $\mathrm{C} 4-\mathrm{H}$ position, leading to a radical $\mathbf{V}$ that is both benzylic and allylic. Addition of an iodine radical may lead to the compound $\mathbf{V I}$, with iodine in $\mathrm{C} 4$, that upon $\mathrm{E} 1 \mathrm{cB}$ elimination reaction leads to the final compound IV.

\section{Conclusions}

A mild, highly efficient synthetic method was developed for the dehydrogenation of 3,4dihydropyrimidin-2(1H)-ones employing in situ formed tert-butyl hypoiodite under basic conditions. The reaction times (3-10 min.) show the superiority of the new method compared to other literature oxidants employed under classical conditions or microwave promoted reactions. Two plausible reaction mechanisms were proposed, via N1-iodo derivative obtained by substitution reaction of anion obtained by deprotonation of 3,4-DHPM and radical mechanism initiated by homolytic cleavage of tert-butyl hypoiodite. 


\section{Experimental Section}

General. All IR spectra were recorded on a Perkin-Elmer Spectrum One spectrophotometer. ${ }^{1} \mathrm{H}$ and ${ }^{13} \mathrm{C}$ NMR spectra were recorded on an AV Bruker $(600 \mathrm{MHz})$ spectrometer, and shifts were given in ppm downfield from TMS as an internal standard. TLC analyses were performed on Merck's (Darmstadt, Germany) DC-alufolien with Kieselgel $60 \mathrm{~F}_{254}$. Melting points were determined using a Büchi B-540 instrument. UV/Vis analyses were performed with a Varian Cary 100 spectrofotometer (Walnut Creek, CA, SAD). HPLC analyses were performed with a Thermo Separation Products (TSP) instrument equipped with vacuum membrane degasser SCM 1000, quaternary gradient pump P 4000, autosampler AS 3000, scanning detector UV 3000HR, controller SN 4000 and software Chromquest (Ver. 2.51). HPLC MS analysis was performed on HPLC Waters Alliance 2795 with PDA detector Waters 996 (210-350 nm) and MS detector Micromass ZMD 4000 (ESI $3.50 \mathrm{kV}$ ). All reagents and solvents were obtained from commercial sources (Sigma Aldrich, Merck) and used without further purification. Dry tetrahydrofuran was prepared by the usual method (using benzophenone and sodium wire) and distilled under a nitrogen atmosphere. Compounds $\mathbf{1}$ and 3-25 were efficiently prepared by a method developed in our laboratory ${ }^{44}$ employing antimony(III) chloride as a catalyst.

General procedure for the dehydrogenation of 3,4-DHPMs. Potassium tert-butoxide (1.60 g, $98 \%, 0.014 \mathrm{~mol}, 2.8$ equiv) was added at once while stirring to a suspension of the corresponding 3,4-DHPM $(5 \mathrm{mmol})$ in dry tetrahydrofuran $(16 \mathrm{~mL})$. The temperature of the reaction mixture was maintained at $20-25^{\circ} \mathrm{C}$ (ice + water), and molecular iodine ( $1.40 \mathrm{~g}, 5 \mathrm{mmol}, 1.1$ equiv) was added. The reaction mixture was stirred at $25{ }^{\circ} \mathrm{C}$ for the time indicated in Table 5 . The progress of reactions was monitored by TLC. After completion of the reaction, dichloromethane ( $8 \mathrm{~mL})$ and diluted hydrochloric acid $(6 \mathrm{~mL}$ of $37 \% \mathrm{HCl}+10 \mathrm{~mL}$ of distilled water) were added to the reaction mixtures. A few drops of the saturated sodium thiosulphate solution were added to complete decoloration. The phases were separated and the aqueous phase was additionally extracted with dichloromethane $(2 \times 8 \mathrm{~mL})$. The combined organic layers were dried over anhydrous sodium sulphate, filtered and evaporated to dryness. The crude products were crystallized from $96 \%$ ethanol. The obtained products were filtered and air dried to a constant weight to obtain the corresponding products. In the case of products that did not crystallize from $96 \%$ ethanol $(\mathbf{2 9}, \mathbf{3 3}, \mathbf{4 2}, \mathbf{4 4}, \mathbf{4 5}, \mathbf{4 6})$, the crude product was purified by column chromatography on $\mathrm{SiO}_{2}$ using the $\mathrm{CH}_{2} \mathrm{Cl}_{2} / \mathrm{MeOH}(9: 1)$ system.

Methyl 6-methyl-4-(2-nitrophenyl)-2-oxo-1,2-dihydropyrimidine-5-carboxylate (28). Yellowish solid, yield 55\%, 0.80 g. $R_{\mathrm{f}}\left(\mathrm{CH}_{2} \mathrm{Cl}_{2} / \mathrm{MeOH}, 9: 1\right) 0.42$; IR (KBr) $v_{\max } 3001,2893$, 2829, 2736, 1736, 1646, 1600, 1539, 1447, 1429, 1370, 1287, 1208, 1136, $1112 \mathrm{~cm}^{-1} .{ }^{1} \mathrm{H}$ NMR (600 MHz, DMSO): $\delta_{\mathrm{H}} 2.52\left(3 \mathrm{H}, \mathrm{s}, \mathrm{CH}_{3}\right), 3.41\left(3 \mathrm{H}, \mathrm{s}, \mathrm{OCH}_{3}\right), 7.43(1 \mathrm{H}, \mathrm{d}, J 7.0 \mathrm{~Hz}$, arom.), $7.70(1 \mathrm{H}, \mathrm{t}, J 8.1 \mathrm{~Hz}$, arom.), $7.82(1 \mathrm{H}, \mathrm{t}, J 7.5 \mathrm{~Hz}$, arom.), 8.20 (1H, d, J 7.8 Hz, arom.), 12.70 $\left(1 \mathrm{H}\right.$, br s, NH). ${ }^{13} \mathrm{C}$ NMR (600 MHz, DMSO): $\delta_{\mathrm{C}} 13.2\left(\mathrm{CH}_{3}\right), 51.7\left(\mathrm{OCH}_{3}\right), 60.5,124.1,129.2$, 
130.0, 134.1, 146.3, $164.5\left(\mathrm{C}=\mathrm{O}\right.$, ester). $\mathrm{MS}(\mathrm{ES}): \mathrm{m} / z$ 290.01 $\left(\mathrm{MH}^{+}\right)$. Anal. Calcd. for $\mathrm{C}_{13} \mathrm{H}_{11} \mathrm{~N}_{3} \mathrm{O}_{5}$ : C 53.98, H 3.83, N 14.53. Found: C 54.10, H 3.74, N 14.40.

Methyl 6-methyl-4-(3-nitrophenyl)-2-oxo-1,2-dihydropyrimidine-5-carboxylate (29). Yellowish solid, yield 74\%, 1.07 g. $R_{\mathrm{f}}\left(\mathrm{CH}_{2} \mathrm{Cl}_{2} / \mathrm{MeOH}, 9: 1\right)$ 0.45; IR (KBr) $v_{\max } 2946,2919$, 2849, 2734, 1718, 1661, 1594, 1531, 1448, 1435, 1419, 1353, 1289, 1273, 1212, 1139, $1114 \mathrm{~cm}^{-}$ 1. ${ }^{1} \mathrm{H}$ NMR (600 MHz, DMSO): $\delta_{\mathrm{H}} 2.47\left(3 \mathrm{H}, \mathrm{s}, \mathrm{CH}_{3}\right), 3.52\left(3 \mathrm{H}, \mathrm{s}, \mathrm{OCH}_{3}\right), 7.79(1 \mathrm{H}, \mathrm{t}, J 8.0 \mathrm{~Hz}$, arom.), 7.87-7.91 (1H, m, arom.), 8.27-8.28 (1H, m, arom.), 8.35-8.39 (1H, m, arom.), 12.65 (1H, br s, NH). ${ }^{13} \mathrm{C}$ NMR (600 MHz, DMSO): $\delta_{\mathrm{C}} 17.0\left(\mathrm{CH}_{3}\right), 52.0\left(\mathrm{OCH}_{3}\right), 122.2,124.7,130.0$, 133.9, 147.5, $165.8\left(\mathrm{C}=\mathrm{O}\right.$, ester). MS (ES): $m / z 290.02\left(\mathrm{MH}^{+}\right)$. Anal. Calcd. for $\mathrm{C}_{13} \mathrm{H}_{11} \mathrm{~N}_{3} \mathrm{O}_{5}$ : C 53.98; H 3.83; N 14.53. Found: C 53.80, H 3.75, N 14.60.

Methyl 6-methyl-4-(4-nitrophenyl)-2-oxo-1,2-dihydropyrimidine-5-carboxylate (30). Pale yellow solid, yield 71\%, $1.03 \mathrm{~g} ; R_{\mathrm{f}}\left(\mathrm{CH}_{2} \mathrm{Cl}_{2} / \mathrm{MeOH}, 9: 1\right)$ 0.44; IR (KBr) $v_{\max } 3037,2950,2903$, 2810, 2755, 1716, 1664, 1609, 1597, 1520, 1431, 1348, 1286, 1209, 1132, $1108 \mathrm{~cm}^{-1} .{ }^{1} \mathrm{H}$ NMR (600 MHz, DMSO): $\delta_{\mathrm{H}} 2.46\left(3 \mathrm{H}, \mathrm{s}, \mathrm{CH}_{3}\right), 3.34\left(3 \mathrm{H}, \mathrm{s}, \mathrm{OCH}_{3}\right), 7.69(2 \mathrm{H}, \mathrm{d}, J 8.7 \mathrm{~Hz}$, arom.), $8.32\left(2 \mathrm{H}, \mathrm{d}, J 8.7 \mathrm{~Hz}\right.$, arom.), $12.62\left(1 \mathrm{H}\right.$, br s, NH). ${ }^{13} \mathrm{C} \mathrm{NMR}(600 \mathrm{MHz}, \mathrm{DMSO}): \delta_{\mathrm{C}} 20.9$ $\left(\mathrm{CH}_{3}\right), 52.0\left(\mathrm{OCH}_{3}\right), 60.9,123.5,128.9,148.1,165.6(\mathrm{C}=\mathrm{O}$, ester $)$. MS (ES): $m / z 290.01\left(\mathrm{MH}^{+}\right)$. Anal. Calcd. for $\mathrm{C}_{13} \mathrm{H}_{11} \mathrm{~N}_{3} \mathrm{O}_{5}$ : C. 53.98; H. 3.83; N 14.53. Found: C 53.95, H 3.80, N 14.40.

Methyl 6-methyl-4-(1-naphthyl)-2-oxo-1,2-dihydropyrimidine-5-carboxylate (33). Yellowish solid, yield 74\%, 1.10 g. $R_{\mathrm{f}}\left(\mathrm{CH}_{2} \mathrm{Cl}_{2} / \mathrm{MeOH}, 9: 1\right)$ 0.46; IR (KBr) $v_{\max } 3110,3046,2949,2928$, 2855, 1720, 1655, 1599, 1508, 1433, 1421, 1320, 1284, 1256, 1220, $1111 \mathrm{~cm}^{-1}$. ${ }^{1} \mathrm{H}$ NMR (600 $\mathrm{MHz}, \mathrm{DMSO}): \delta_{\mathrm{H}} 2.48\left(3 \mathrm{H}, \mathrm{s}, \mathrm{CH}_{3}\right), 3.36\left(3 \mathrm{H}, \mathrm{s}, \mathrm{OCH}_{3}\right), 7.40(1 \mathrm{H}, \mathrm{d}, J 6.6 \mathrm{~Hz}$, arom.), 7.49$7.61(3 \mathrm{H}, \mathrm{m}$, arom.), $7.76(1 \mathrm{H}, \mathrm{d}, J 7.7 \mathrm{~Hz}$, arom.), 7.99-8.03 (2H, m, arom.), 12.56 (1H, br s, $\mathrm{NH}) .{ }^{13} \mathrm{C}$ NMR $(600 \mathrm{MHz}, \mathrm{DMSO}): \delta_{\mathrm{C}} 22.0\left(\mathrm{CH}_{3}\right), 51.4\left(\mathrm{OCH}_{3}\right), 124.7,125.0,126.1,126.6$, 128.2, 129.7, 132.7, $165.5\left(\mathrm{C}=\mathrm{O}\right.$, ester). $\mathrm{MS}(\mathrm{ES}): \mathrm{m} / z 295.07\left(\mathrm{MH}^{+}\right)$. Anal. Calcd. for $\mathrm{C}_{17} \mathrm{H}_{14} \mathrm{~N}_{2} \mathrm{O}_{3}$ : C 69.38; H 4.79; N 9.52. Found: C 69.50, H 4.69, N 9.40.

Methyl 6-isopropyl-4-(2-chlorophenyl)-2-oxo-1,2-dihydropyrimidine-5-carboxylate (35). White solid, yield 78\%, $1.19 \mathrm{~g} ; R_{\mathrm{f}}\left(\mathrm{CH}_{2} \mathrm{Cl}_{2} / \mathrm{MeOH}, 9: 1\right)$ 0.50; IR (KBr) $v_{\max } 2981,2928,2868$, 2837, 2748, 1722, 1655, 1597, 1585, 1554, 1471, 1430, 1348, 1318, 1272, 1249, 1130, 1108, 1080, $1047 \mathrm{~cm}^{-1} .{ }^{1} \mathrm{H}$ NMR (600 MHz, DMSO): $\delta_{\mathrm{H}} 1.28\left(6 \mathrm{H}, \mathrm{d}, J 6.0 \mathrm{~Hz}, \mathrm{CH}\left(\mathrm{CH}_{3}\right)_{2}\right), 3.28-3.37$ $\left(1 \mathrm{H}, \mathrm{m}, \mathrm{CH}\left(\mathrm{CH}_{3}\right)_{2}\right), 3.46\left(3 \mathrm{H}, \mathrm{s}, \mathrm{OCH}_{3}\right), 7.43-7.62(4 \mathrm{H}, \mathrm{m}$, arom. $), 12.48(1 \mathrm{H}$, br s, $\mathrm{NH}) .{ }^{13} \mathrm{C}$ NMR (600 MHz, DMSO): $\delta_{\mathrm{C}} 18.8\left(\mathrm{CH}_{3}\right), 19.2\left(\mathrm{CH}_{3}\right), 26.9,52.0\left(\mathrm{OCH}_{3}\right), 96.7,127.0,127.8$, 128.3, 129.2, 131.7, 141.4, 151.9, 157.3, 165.5 (C=O, ester). MS (ES): $m / z 307.03\left(\mathrm{MH}^{+}\right)$. Anal. Calcd. for $\mathrm{C}_{15} \mathrm{H}_{15} \mathrm{ClN}_{2} \mathrm{O}_{3}$ : C 58.73, $\mathrm{H}$ 4.93, N 9.13. Found: C 58.80, H 4.85, N 9.25.

Methyl 6-isopropyl-4-(3-chlorophenyl)-2-oxo-1,2-dihydropyrimidine-5-carboxylate (36). White solid, yield 77\%, $1.18 \mathrm{~g} ; R_{\mathrm{f}}\left(\mathrm{CH}_{2} \mathrm{Cl}_{2} / \mathrm{MeOH}, 9: 1\right)$ 0.60; IR (KBr) $v_{\max } 2998,2979,2944$, 2903, 2883, 2842, 1722, 1653, 1596, 1542, 1444, 1436, 1414, 1383, 1337, 1278, 1263, 1204, $1126 \mathrm{~cm}^{-1} .{ }^{1} \mathrm{H}$ NMR $(600 \mathrm{MHz}, \mathrm{DMSO}): \delta_{\mathrm{H}} 1.24\left(6 \mathrm{H}, \mathrm{d}, J 6.8 \mathrm{~Hz}, \mathrm{CH}\left(\mathrm{CH}_{3}\right)_{2}\right), 3.07-3.16(1 \mathrm{H}, \mathrm{m}$, $\left.\mathrm{CH}\left(\mathrm{CH}_{3}\right)_{2}\right), 3.55\left(3 \mathrm{H}, \mathrm{s}, \mathrm{OCH}_{3}\right), 7.41(1 \mathrm{H}, \mathrm{d}, J 7.6 \mathrm{~Hz}$, arom.), 7.50-7.61 (3H, m, arom.), 12.34 $\left(1 \mathrm{H}\right.$, br s, NH). ${ }^{13} \mathrm{C} \mathrm{NMR}(600 \mathrm{MHz}, \mathrm{DMSO}): \delta_{\mathrm{C}} 20.5\left(\mathrm{CH}_{3}\right), 52.4\left(\mathrm{OCH}_{3}\right), 126.2,127.5,130.3$, 
130.4, 133.2, $166.9\left(\mathrm{C}=\mathrm{O}\right.$, ester). MS (ES): $m / z$ 307.04 $\left(\mathrm{MH}^{+}\right)$. Anal. Calcd. for $\mathrm{C}_{15} \mathrm{H}_{15} \mathrm{ClN}_{2} \mathrm{O}_{3}$ : C 58.73, H 4.93, N 9.13. Found: C 58.80, H 4.85, N 9.20.

Methyl 6-isopropyl-4-(4-chlorophenyl)-2-oxo-1,2-dihydropyrimidine-5-carboxylate (37). White solid, yield 92\%, 1.41 g. $R_{\mathrm{f}}\left(\mathrm{CH}_{2} \mathrm{Cl}_{2} / \mathrm{MeOH}, 9: 1\right)$ 0.58; IR (KBr) $v_{\max } 2993,2969,2944$, 2885, 2838, 1719, 1655, 1591, 1570, 1431, 1404, 1387, 1340, 1318, 1279, 1203, 1123, 1108, $1087 \mathrm{~cm}^{-1} .{ }^{1} \mathrm{H}$ NMR $(600 \mathrm{MHz}, \mathrm{DMSO}): \delta_{\mathrm{H}} 1.23\left(6 \mathrm{H}, \mathrm{d}, J 6.8 \mathrm{~Hz}, \mathrm{CH}\left(\mathrm{CH}_{3}\right)_{2}\right), 3.04-3.18(1 \mathrm{H}, \mathrm{m}$, $\left.\mathrm{CH}\left(\mathrm{CH}_{3}\right)_{2}\right), 3.57\left(3 \mathrm{H}, \mathrm{s}, \mathrm{OCH}_{3}\right), 7.54\left(4 \mathrm{H}, \mathrm{q}, J_{1} 8.6 \mathrm{~Hz}, J_{2} 18.6 \mathrm{~Hz}\right.$, arom.), 12.27 (1H, br s, NH). ${ }^{13} \mathrm{C}$ NMR (600 MHz, DMSO): $\delta_{\mathrm{C}} 20.5\left(\mathrm{CH}_{3}\right), 52.5\left(\mathrm{OCH}_{3}\right), 128.6,129.5,135.4,167.0(\mathrm{C}=\mathrm{O}$, ester). MS (ES): $m / z 306.97\left(\mathrm{MH}^{+}\right)$. Anal. Calcd. for $\mathrm{C}_{15} \mathrm{H}_{15} \mathrm{ClN}_{2} \mathrm{O}_{3}$ : C 58.73, H 4.93, N 9.13. Found: C 58.75, H 4.85, N 9.25.

Methyl 6-isopropyl-4-(2-nitrophenyl)-2-oxo-1,2-dihydropyrimidine-5-carboxylate (38). Yellowish solid, yield 78\%, 1.24 g. $R_{\mathrm{f}}\left(\mathrm{CH}_{2} \mathrm{Cl}_{2} / \mathrm{MeOH}, 9: 1\right)$ 0.57; IR (KBr) $v_{\max } 3004,2980$, 2919, 2883, 1726, 1654, 1599, 1527, 1429, 1403, 1390, 1351, 1311, 1277, 1259, 1203, $1129 \mathrm{~cm}^{-}$ 1. ${ }^{1} \mathrm{H}$ NMR (600 MHz, DMSO): $\delta_{\mathrm{H}} 1.26\left(6 \mathrm{H}, \mathrm{d}, J 6.8 \mathrm{~Hz}, \mathrm{CH}\left(\mathrm{CH}_{3}\right)_{2}\right), 3.23-3.35(1 \mathrm{H}, \mathrm{m}$, $\left.\mathrm{CH}\left(\mathrm{CH}_{3}\right)_{2}\right), 3.41\left(3 \mathrm{H}, \mathrm{s}, \mathrm{OCH}_{3}\right), 7.53(1 \mathrm{H}, \mathrm{d}, J 7.5 \mathrm{~Hz}$, arom.), 7.76 (1H, t, J 7.8 Hz, arom.), 7.86 (1H, t, $J 7.5 \mathrm{~Hz}$, arom.), 8.24 (1H, d, J 7.7 Hz, arom.). ${ }^{13} \mathrm{C} \mathrm{NMR}(600 \mathrm{MHz}, \mathrm{DMSO}): \delta_{\mathrm{C}} 20.5$ $\left(\mathrm{CH}_{3}\right), 31.5,52.1\left(\mathrm{OCH}_{3}\right), 124.4,129.7,130.8,134.2,146.5,165.3(\mathrm{C}=\mathrm{O}$, ester $) . \mathrm{MS}(\mathrm{ES}): \mathrm{m} / z$ $318.01\left(\mathrm{MH}^{+}\right)$. Anal. Calcd. for $\mathrm{C}_{15} \mathrm{H}_{15} \mathrm{~N}_{3} \mathrm{O}_{5}$ : C 56.78, H 4.76, N 13.24. Found: C 56.85, H 4.85, N 13.35.

Methyl 6-isopropyl-4-(2,4-dimethylphenyl)-2-oxo-1,2-dihydropyrimidine-5-carboxylate (39). White solid, yield 68\%, 1.02 g. $R_{\mathrm{f}}\left(\mathrm{CH}_{2} \mathrm{Cl}_{2} / \mathrm{MeOH}, 9: 1\right)$ 0.55; IR (KBr) $v_{\max } 2971,2954$, 2932, 2872, 2754, 1730, 1651, 1598, 1549, 1439, 1319, 1268, 1200, $1122 \mathrm{~cm}^{-1} .{ }^{1} \mathrm{H}$ NMR (600 MHz, DMSO): $\delta_{\mathrm{H}} 1.20\left(6 \mathrm{H}, \mathrm{d}, J 6.7 \mathrm{~Hz}, \mathrm{CH}\left(\mathrm{CH}_{3}\right)_{2}\right), 2.16\left(3 \mathrm{H}, \mathrm{s}, \mathrm{CH}_{3}\right), 2.31\left(3 \mathrm{H}, \mathrm{s}, \mathrm{CH}_{3}\right), 3.05-$ $3.14\left(1 \mathrm{H}, \mathrm{m}, \mathrm{CH}\left(\mathrm{CH}_{3}\right)_{2}\right), 3.40\left(3 \mathrm{H}, \mathrm{s}, \mathrm{OCH}_{3}\right), 7.02-7.08(2 \mathrm{H}, \mathrm{m}$, arom.), $7.13(1 \mathrm{H}$, s, arom.), $12.23\left(1 \mathrm{H}\right.$, br s, NH). ${ }^{13} \mathrm{C} \mathrm{NMR}(600 \mathrm{MHz}, \mathrm{DMSO}): \delta_{\mathrm{C}} 19.0\left(\mathrm{CH}_{3}\right), 20.8\left(\mathrm{CH}_{3}\right), 32.6,52.1$ $\left(\mathrm{OCH}_{3}\right), 126.1,127.5,130.8,135.0,139.2,166.3\left(\mathrm{C}=\mathrm{O}\right.$, ester). $\mathrm{MS}(\mathrm{ES}): \mathrm{m} / z 301.35\left(\mathrm{MH}^{+}\right)$. Anal. Calcd. for $\mathrm{C}_{17} \mathrm{H}_{20} \mathrm{~N}_{2} \mathrm{O}_{3}$ : C 67.98, H 6.71, N 9.33. Found: C 67.80, H 6.80, N 9.45.

Methyl 6-isopropyl-4-(4-methylphenyl)-2-oxo-1,2-dihydropyrimidine-5-carboxylate (40). Yellowish solid, yield $70 \%, 1.00$ g. $R_{\mathrm{f}}\left(\mathrm{CH}_{2} \mathrm{Cl}_{2} / \mathrm{MeOH}, 9: 1\right)$ 0.52; IR (KBr) $v_{\max } 2972,2885$, 2840, 2747, 1716, 1654, 1597, 1429, 1404, 1388, 1341, 1277, 1205, 1189, 1126, $1075 \mathrm{~cm}^{-1} .{ }^{1} \mathrm{H}$ NMR (600 MHz, DMSO): $\delta_{\mathrm{H}} 1.22\left(6 \mathrm{H}, \mathrm{d}, J 6.8 \mathrm{~Hz}, \mathrm{CH}\left(\mathrm{CH}_{3}\right)_{2}\right), 2.37\left(3 \mathrm{H}, \mathrm{s}, \mathrm{CH}_{3}\right), 3.02-3.11$ $\left(1 \mathrm{H}, \mathrm{m}, \mathrm{CH}\left(\mathrm{CH}_{3}\right)_{2}\right), 3.56\left(3 \mathrm{H}, \mathrm{s}, \mathrm{OCH}_{3}\right), 7.31(2 \mathrm{H}, \mathrm{d}, J 8.1 \mathrm{~Hz}$, arom.), $7.40(2 \mathrm{H}, \mathrm{d}, J 8.2 \mathrm{~Hz}$, arom.), $12.20\left(1 \mathrm{H}\right.$, br s, NH). ${ }^{13} \mathrm{C}$ NMR (600 MHz, DMSO): $\delta_{\mathrm{C}} 20.5\left(\mathrm{CH}_{3}\right), 20.9\left(\mathrm{CH}_{3}\right), 31.8$, $52.4\left(\mathrm{OCH}_{3}\right), 127.6,129.1,140.6,167.3\left(\mathrm{C}=\mathrm{O}\right.$, ester). MS (ES): $m / z 287.07\left(\mathrm{MH}^{+}\right)$. Anal. Calcd. for $\mathrm{C}_{16} \mathrm{H}_{18} \mathrm{~N}_{2} \mathrm{O}_{3}$ : C 67.12, H 6.34, N 9.78. Found: C 67.05, H 6.41, N 9.65.

Methyl 6-isopropyl-4-(4-methoxyphenyl)-2-oxo-1,2-dihydropyrimidine-5-carboxylate (41). White solid, yield 91\%, 1.37 g. $R_{\mathrm{f}}\left(\mathrm{CH}_{2} \mathrm{Cl}_{2} / \mathrm{MeOH}, 9: 1\right)$ 0.56; IR (KBr) $v_{\max } 3017,2977,2950$, 2910, 1717, 1643, 1591, 1516, 1434, 1398, 1387, 1300, 1278, 1257, 1208, 1178, 1124, $1021 \mathrm{~cm}^{-}$ ${ }^{1} .{ }^{1} \mathrm{H}$ NMR (600 MHz, DMSO): $\delta_{\mathrm{H}} 1.23\left(6 \mathrm{H}, \mathrm{d}, J 6.8 \mathrm{~Hz}, \mathrm{CH}\left(\mathrm{CH}_{3}\right)_{2}\right), 3.02-3.11(1 \mathrm{H}, \mathrm{m}$, $\left.\mathrm{CH}\left(\mathrm{CH}_{3}\right)_{2}\right), 3.60\left(3 \mathrm{H}, \mathrm{s}, \mathrm{OCH}_{3}\right), 3.83\left(3 \mathrm{H}, \mathrm{s}, \mathrm{OCH}_{3}\right), 7.06(2 \mathrm{H}, \mathrm{d}, J 8.8 \mathrm{~Hz}$, arom.); 7.49 (2H, d, J 
$8.7 \mathrm{~Hz}$, arom.), 12.14 (1H, br s, NH). ${ }^{13} \mathrm{C}$ NMR (600 MHz, DMSO): $\delta_{\mathrm{C}} 20.6\left(\mathrm{CH}_{3}\right), 27.7,52.4$ $\left(\mathrm{OCH}_{3}\right), 55.4\left(\mathrm{OCH}_{3}\right), 114.0,129.5,161.3,167.5\left(\mathrm{C}=\mathrm{O}\right.$, ester). MS (ES): $\mathrm{m} / \mathrm{z} 303.10\left(\mathrm{MH}^{+}\right)$. Anal. Calcd. for $\mathrm{C}_{16} \mathrm{H}_{18} \mathrm{~N}_{2} \mathrm{O}_{4}$ : C 63.56, H 6.00, N 9.27. Found: C 63.65, H 6.05, N 9.35.

Isopropyl 6-methyl-4-phenyl-2-oxo-1,2-dihydropyrimidine-5-carboxylate (43). Yellowish solid, yield 86\%, 1.17 g. $R_{\mathrm{f}}\left(\mathrm{CH}_{2} \mathrm{Cl}_{2} / \mathrm{MeOH}, 9: 1\right)$ 0.40; IR $(\mathrm{KBr}) v_{\max } 2982,2933,2898,2829$, 2734, 1723, 1646, 1601, 1457, 1430, 1284, 1209, $1090 \mathrm{~cm}^{-1} .{ }^{1} \mathrm{H}$ NMR (600 MHz, DMSO): $\delta_{\mathrm{H}}$ $0.92\left(6 \mathrm{H}, \mathrm{d}, J 6.2 \mathrm{~Hz}, \mathrm{OCH}\left(\mathrm{CH}_{3}\right)_{2}\right), 2.39\left(3 \mathrm{H}, \mathrm{s}, \mathrm{CH}_{3}\right), 4.73-4.86\left(1 \mathrm{H}, \mathrm{m}, \mathrm{OCH}\left(\mathrm{CH}_{3}\right)_{2}\right), 7.45-7.47$ (3H, m, arom.), 7.49-7.52 (2H, m, arom.), 12.30 (1H, br s, NH). ${ }^{13} \mathrm{C}$ NMR (600 MHz, DMSO): $\delta_{\mathrm{C}} 20.9\left(\mathrm{CH}_{3}\right), 68.7(\mathrm{OCH}), 127.5,128.3,130.1,166.3(\mathrm{C}=\mathrm{O}$, ester). MS (ES): $m / z 273.03$ $\left(\mathrm{MH}^{+}\right)$. Anal. Calcd. for $\mathrm{C}_{15} \mathrm{H}_{16} \mathrm{~N}_{2} \mathrm{O}_{3}$ : C 66.16, H 5.92, N 10.29. Found: $\mathrm{C}$ 66.30, H 5.80, N 10.10 .

Isobutyl 6-methyl-4-phenyl-2-oxo-1,2-dihydropyrimidine-5-carboxylate (44). Yellowish solid, yield 78\%, 1.11 g. $R_{\mathrm{f}}\left(\mathrm{CH}_{2} \mathrm{Cl}_{2} / \mathrm{MeOH}, 9: 1\right)$ 0.44; IR (KBr) $v_{\max } 2960,2936,2873,2741$, $1719,1662,1645,1599,1580,1553,1455,1422,1377,1279,1208,1137,1105,1081 \mathrm{~cm}^{-1} .{ }^{1} \mathrm{H}$ NMR (600 MHz, DMSO): $\delta_{\mathrm{H}} 0.57\left(6 \mathrm{H}, \mathrm{d}, J 6.8 \mathrm{~Hz}, \mathrm{CH}\left(\mathrm{CH}_{3}\right)_{2}\right), 1.47-1.52\left(1 \mathrm{H}, \mathrm{m}, \mathrm{CH}\left(\mathrm{CH}_{3}\right)_{2}\right)$, $2.41\left(3 \mathrm{H}, \mathrm{s}, \mathrm{CH}_{3}\right), 3.69\left(2 \mathrm{H}, \mathrm{d}, J 6.5 \mathrm{~Hz}, \mathrm{OCH}_{2}\right), 7.46-7.48\left(5 \mathrm{H}, \mathrm{m}\right.$, arom.). ${ }^{13} \mathrm{C} \mathrm{NMR}(600 \mathrm{MHz}$, DMSO): $\delta_{\mathrm{C}} 13.2\left(\mathrm{CH}_{3}\right), 18.4\left(\mathrm{CH}_{3}\right), 26.5,60.8\left(\mathrm{OCH}_{2}\right), 70.9,127.4,128.2,128.3,130.1,130.2$, $166.1\left(\mathrm{C}=\mathrm{O}\right.$, ester). $\mathrm{m} / \mathrm{z} 287.08\left(\mathrm{MH}^{+}\right)$. Anal. Calcd. for $\mathrm{C}_{16} \mathrm{H}_{18} \mathrm{~N}_{2} \mathrm{O}_{3}$ : C 67.12; H 6.34; $\mathrm{N} 9.78$. Found: C 67.20, H 6.45, N 9.60.

Benzyl 6-methyl-4-phenyl-2-oxo-1,2-dihydropyrimidine-5-carboxylate (45). Yellowish solid, yield 77\%, $1.22 \mathrm{~g} ; R_{\mathrm{f}}\left(\mathrm{CH}_{2} \mathrm{Cl}_{2} / \mathrm{MeOH}, 9: 1\right)$ 0.42; IR (KBr) $v_{\max } 3060,3032,2925,2852,1720$, 1655, 1600, 1496, 1454, 1420, 1377, 1276, 1202, 1132, $1098 \mathrm{~cm}^{-1} .{ }^{1} \mathrm{H}$ NMR (600 MHz, DMSO): $\delta_{\mathrm{H}} 2.41\left(3 \mathrm{H}, \mathrm{s}, \mathrm{CH}_{3}\right), 4.99\left(2 \mathrm{H}, \mathrm{s}, \mathrm{OCH}_{2}\right), 7.24-7.24(1 \mathrm{H}, \mathrm{m}$, arom.), 7.26-7.27 (3H, m, arom.), 7.28-7.28 (1H, m, arom.), 7.42-7.43 (1H, m, arom.), 7.45-7.45 (3H, m, arom.), 7.47-7.48 (1H, m, arom.), $12.42\left(1 \mathrm{H}\right.$, br s, NH). ${ }^{13} \mathrm{C}$ NMR (600 MHz, DMSO): $\delta_{\mathrm{C}} 25.9\left(\mathrm{CH}_{3}\right), 67.3\left(\mathrm{OCH}_{2}\right), 126.8$, 128.0, 128.6, 128.7, 128.8, 130.8, 135.3, 166.3 (C=O, ester). MS (ES): $m / z 321.11\left(\mathrm{MH}^{+}\right)$. Anal. Calcd. for $\mathrm{C}_{19} \mathrm{H}_{16} \mathrm{~N}_{2} \mathrm{O}_{3}$ : C 71.24; H 5.03; N 8.74. Found: C 71.35, H 5.15, N 8.70.

Ethyl 6-methyl-4-(2-naphthyl)-2-oxo-1,2-dihydropyrimidine-5-carboxylate (46). Yellowish solid, yield 72\%, 1.11 g. $R_{\mathrm{f}}\left(\mathrm{CH}_{2} \mathrm{Cl}_{2} / \mathrm{MeOH}, 9: 1\right)$ 0.49; IR (KBr) $v_{\max } 3420,2981,2918,1725$, $1638,1588,1444,1424,1388,1367,1286,1242,1120,1097 \mathrm{~cm}^{-1} .{ }^{1} \mathrm{H}$ NMR (600 MHz, DMSO): $\delta_{\mathrm{H}} 2.46\left(3 \mathrm{H}, \mathrm{s}, \mathrm{CH}_{3}\right), 3.33\left(3 \mathrm{H}, \mathrm{s}, \mathrm{OCH}_{2} \mathrm{CH}_{3}\right), 3.95\left(2 \mathrm{H}, \mathrm{q}, J 14.2 \mathrm{~Hz}, \mathrm{OCH}_{2} \mathrm{CH}_{3}\right), 7.55-7.58(1 \mathrm{H}$, $\mathrm{m}$, arom.), 7.59-7.62 (2H, m, arom.), 7.98-8.02 (2H, m, arom.), 8.03-8.05 (2H, m, arom.), 12.44 $\left(1 \mathrm{H}\right.$, br s, NH). ${ }^{13} \mathrm{C}$ NMR (600 MHz, DMSO): $\delta_{\mathrm{C}} 13.2\left(\mathrm{CH}_{3}\right), 14.0\left(\mathrm{CH}_{3}\right), 60.8\left(\mathrm{OCH}_{2}\right), 124.8$, 126.8, 127.6, 127.7, 128.5, 132.2, 133.4, 166.0 (C=O, ester). MS (ES): $m / z$ 309.12 $\left(\mathrm{MH}^{+}\right)$. Anal. Calcd. for $\mathrm{C}_{18} \mathrm{H}_{16} \mathrm{~N}_{2} \mathrm{O}_{3}$ : C 70.12; H 5.23; N 9.09. Found: C 69.95, H 5.30, N 9.15.

Methyl 6-isopropyl-4-(1-naphthyl)-2-oxo-1,2-dihydropyrimidine-5-carboxylate (47). Yellowish solid, yield 73\%, 1.17 g. $R_{\mathrm{f}}\left(\mathrm{CH}_{2} \mathrm{Cl}_{2} / \mathrm{MeOH}, 9: 1\right)$ 0.60; IR (KBr) $v_{\max } 2987,2975$, 2959, 2932, 2909, 1722, 1651, 1571, 1540, 1433, 1333, 1273, 1255, 1214, 1140, $1114 \mathrm{~cm}^{-1} .{ }^{1} \mathrm{H}$ NMR (600 MHz, DMSO): $\delta_{\mathrm{H}} 1.27\left(6 \mathrm{H}, \mathrm{d}, J 6.7 \mathrm{~Hz}, \mathrm{CH}\left(\mathrm{CH}_{3}\right)_{2}\right), 3.14\left(3 \mathrm{H}, \mathrm{s}, \mathrm{OCH}_{3}\right), 3.18-3.25$ $\left(1 \mathrm{H}, \mathrm{m}, \mathrm{CH}\left(\mathrm{CH}_{3}\right)_{2}\right), 7.47$ (1H, d, J $6.9 \mathrm{~Hz}$, arom.), 7.53-7.60 (3H, m, arom.), 7.72 (1H, d, J 6.9 
$\mathrm{Hz}$, arom.), 8.00-8.07 (2H, m, arom.), 12.40 (1H, br s, NH). ${ }^{13} \mathrm{C}$ NMR (600 MHz, DMSO): $\delta_{\mathrm{C}}$ $21.3\left(\mathrm{CH}_{3}\right), 52.3\left(\mathrm{OCH}_{3}\right), 125.2,125.5,126.9,127.4,128.8,130.3,130.4,133.3,166.6(\mathrm{C}=\mathrm{O}$, ester). MS (ES): $m / z 323.12\left(\mathrm{MH}^{+}\right)$. Anal. Calcd. for $\mathrm{C}_{19} \mathrm{H}_{18} \mathrm{~N}_{2} \mathrm{O}_{3}: \mathrm{C} 70.79, \mathrm{H}$ 5.63, N 8.69. Found: C 70.85, H 5.70, N 8.60.

Methyl 6-isopropyl-4-(2-methoxyphenyl)-2-oxo-1,2-dihydropyrimidine-5-carboxylate (48). White solid, yield 94\%, 1.41 g. $R_{\mathrm{f}}\left(\mathrm{CH}_{2} \mathrm{Cl}_{2} / \mathrm{MeOH}, 9: 1\right)$ 0.50; IR (KBr) $v_{\max } 3075,2986,2970$, 2948, 1726, 1692, 1646, 1605, 1592, 1572, 1538, 1498, 1459, 1431, 1342, 1318, 1293, 1263, 1124, $1019 \mathrm{~cm}^{-1} .{ }^{1} \mathrm{H}$ NMR (600 MHz, DMSO): $\delta_{\mathrm{H}} 1.22\left(6 \mathrm{H}, \mathrm{d}, J\right.$ 6,8 Hz, $\left.\mathrm{CH}\left(\mathrm{CH}_{3}\right)_{2}\right), 3.19-3.33$ $\left(1 \mathrm{H}, \mathrm{m}, \mathrm{CH}\left(\mathrm{CH}_{3}\right)_{2}\right), 3.46\left(3 \mathrm{H}, \mathrm{s}, \mathrm{OCH}_{3}\right), 3.74\left(3 \mathrm{H}, \mathrm{s}, \mathrm{OCH}_{3}\right), 7.01-7.10$ (2H, m, arom.), 7.30 (1H, d, J 7.5 Hz, arom.), 7.46 (1H, t, J 7.9 Hz, arom.), $11.99\left(1 \mathrm{H}\right.$, br s, NH). ${ }^{13} \mathrm{C}$ NMR (600 $\mathrm{MHz}, \mathrm{DMSO}): \delta_{\mathrm{C}} 21.2\left(\mathrm{CH}_{3}\right), 32.4,52.0\left(\mathrm{OCH}_{3}\right), 55.9\left(\mathrm{OCH}_{3}\right), 111.6,120.7,130.0,132.1$, 156.6, 157.2, $166.5\left(\mathrm{C}=\mathrm{O}\right.$, ester). MS (ES): $m / z 303.08\left(\mathrm{MH}^{+}\right)$. Anal. Calcd. for $\mathrm{C}_{16} \mathrm{H}_{18} \mathrm{~N}_{2} \mathrm{O}_{4}$ : C 63.56, H 6.00, N 9.27. Found: C 63.40, H 6.10, N 9.35.

\section{Acknowledgements}

The authors wish to express their gratitude to Belupo Pharmaceuticals Inc. for the financial support of this study.

\section{References}

1. Kappe, C. O. Acc. Chem. Res. 2000, 33, 879. http://dx.doi.org/10.1021/ar000048h

2. Matache, M.; Dobrota, C.; Bogdan, N. D.; Funeriu, D. P. Curr. Org. Synth. 2011, 8, 356. http://dx.doi.org/10.2174/157017911795529218

3. Biginelli, P. Gazz. Chim. Ital. 1893, 23, 360.

4. Suresh; Sandhu, J. S. Arkivoc 2012, (i), 66. http://dx.doi.org/10.3998/ark.5550190.0013.103

5. Guengerich, F. P.; Martin, M. V.; Beaune, P. H.; Kremers, P.; Wolf, T.; Waxman, D. J. J. Biol. Chem. 1986, 261, 5051.

6. Tamaddon, F.; Razmi, Z.; Synth. Commun. 2011, 41, 485. http://dx.doi.org/10.1080/00397911003587523

7. Memarian H. R.; Farhadi A. Monatsh. Chem. 2009, 140, 1217. http://dx.doi.org/10.1007/s00706-009-0156-0

8. Memarian, H. R.; Farhadi, A.; Sabzyan, H.; Soleymani, M. J. Photochem. Photobiol. A Chem. 2010, 209, 95.

http://dx.doi.org/10.1016/j.jphotochem.2009.10.012 
9. Vanden Eynde, J. J.; Audiart, N.; Canonne, V.; Michel, S.; Van Haverbeke Y.; Kappe, C. O. Heterocycles 1997, 45, 1967.

http://dx.doi.org/10.3987/COM-97-7931

10. Kappe, C. O. Tetrahedron 1993, 49, 6937.

http://dx.doi.org/10.1016/S0040-4020(01)87971-0

11. Shanmugam, P.; Perumal, P. T. Tetrahedron 2007, 63, 666.

http://dx.doi.org/10.1016/J.TET.2006.11.010

12. Yamamoto, K.; Chen, Y. G.; Buono, F. G. Org. Lett. 2005, 7, 4673.

http://dx.doi.org/10.1021/ol051879w

13. Shanmugam, P.; Perumal, P. T. Tetrahedron 2006, 62, 9726.

http://dx.doi.org/10.1016/j.tet.2006.07.063

14. Karade, N. N.; Gampawar, S. V.; Kondre, J. M.; Tiwari, G. B. Tetrahedron Lett. 2008, 49, 6698.

http://dx.doi.org/10.1016/j.tetlet.2008.09.045

15. Singh, K.; Singh, K. Aust. J. Chem. 2008, 61, 910.

http://dx.doi.org/10.1071/CH07432

16. Memarian, H. R.; Farhadi, A. Ultrasonics Sonochem. 2008, 15, 1015.

http://dx.doi.org/10.1016/j.ultsonch.2008.02.014

17. Kawashita, Y.; Hayashi, M. Molecules 2009, 14, 3073.

http://dx.doi.org/10.3390/molecules14083073

18. Memarian, H. R.; Sabzyan, H.; Farhadi A. Z. Naturforsch. 2009, 64b, 532.

19. Liang, R. R.; Wu, G. L.; Wu, W. T.; Wu, L. M. Chin. Chem. Lett. 2009, 20, 1183. http://dx.doi.org/10.1016/j.cclet.2009.04.039

20. Nasr-Esfahani, M.; Montazerozohori, M.; Abdi, K. Arkivoc 2009, (x), 255. http://dx.doi.org/10.3998/ark.5550190.0010.a23

21. Memarian, H. R.; Ranjbar, M. J. Mol. Catal. Chem. 2012, 356, 46. http://dx.doi.org/10.1016/j.molcata.2011.12.026

22. Memarian, H. R.; Farhadi, A. J. Iran. Chem. Soc. 2009, 6, 638.

23. Memarian, H. R.; Farhadi, A.; Sabzyan, H. Ultrasonics Sonochem. 2010, 17, 579. http://dx.doi.org/10.1016/j.ultsonch.2009.11.014

24. Han, B.; Han, R.-F.; Ren, Y.-W.; Duan, X.-Y.; Xu, Y.-C.; Zhang, W. Tetrahedron 2011, 67, 5615 .

http://dx.doi.org/10.1016/j.tet.2011.05.105

25. Liu, Q.; Li, Y.-N.; Zhang, H.-H.; Chen, B.; Tung, C.-H.; Wu, L.-Z. J. Org. Chem. 2011, 76, 1444.

http://dx.doi.org/10.1021/jo102062u

26. Karade, H. N.; Acharya, J.; Kaushik, M. P. Tetrahedron Lett. 2012, 53, 5541. http://dx.doi.org/10.1016/j.tetlet.2012.08.017

27. Kodape M. M.; Aswar A. S.; Gawhale, N. D.; Humne, V. T.; Mir, B. A. Chin. Chem. Lett. 2012, 23, 1339. 
http://dx.doi.org/10.1016/j.cclet.2012.10.015

28. Memarian, H. R.; Hejazi, L.; Farhadi, A. Z. Naturforsch. 2012, 67b, 263.

29. Gorjizadeh, M. Bull. Korean Chem. Soc. 2013, 34, 1751. http://dx.doi.org/10.5012/bkcs.2013.34.6.1751

30. Bhong, B. Y.; Shelke, A. V.; Karade N. N. Tetrahedron Lett. 2013, 54, 739. http://dx.doi.org/10.1016/j.tetlet.2012.10.131

31. Bhong, B. Y.; Thorat, P. B.; Karade N. N. Tetrahedron Lett. 2013, 54, 1862. http://dx.doi.org/10.1016/j.tetlet.2013.01.099

32. Phan, N. H. T.; Sohn J.-H. Tetrahedron 2014, 70, 7929. http://dx.doi.org/10.1016/j.tet.2014.08.057

33. Memarian, H. R.; Ranjbar, M.; Sabzyan, H.; Kiani A. C. R. Chimie 2012, 15, 1001. http://dx.doi.org/10.1016/j.crci.2012.09.009

34. Cepanec, I.; Litvić, M.; Pogorelić, I. Org. Process Res. Dev. 2006, 10, 1192. http://dx.doi.org/10.1021/op068009u

35. Zeynizadeh, B.; Dilmaghani, K. A.; Roozijoy, A. J. Chin. Chem. Soc. 2005, 52, 1001. http://dx.doi.org/10.1002/jccs.200500139

36. Filipan-Litvić M.; Litvić, M.; Vinković, V. Tetrahedron 2008, 64, 5649. http://dx.doi.org/10.1016/j.tet.2008.04.040

37. Potassium tert-butoxide (KTB), powder, Rockwood Lithium, Date of Issue: 09/2012, www.rockwoodlithium.com

38. Tanner, D. D.; Gidley, G. C.; Das, N.; Rowe, J. E.; Potter, A. J. Am. Chem. Soc. 1984, 106, 5261.

http://dx.doi.org/10.1021/ja00330a038

39. Barton, D. H. R.; Beckwith, A. L. J.; Goosen, A. J. J. Chem. Soc. 1965, 181. http://dx.doi.org/10.1039/JR9650000181

40. Barton, D. H. R.; Faro, H. P.; Serebryakov, E. P.; Woolsey, N. F. J. Chem. Soc. 1965, 2438.

http://dx.doi.org/10.1039/JR9650002438

41. Britten-Kelly M. R.; Goosen, A.; Lovelock, J.; Scheffer, A. J. Chem. Soc., Perkin Trans 1, $1977,945$. http://dx.doi.org/10.1039/P19770000945

42. Togo, H. Advanced Free Radical Reactions for Organic Synthesis; Elsevier: Amsterdam, 2004; p 172.

43. Zard, S. Z. Radical Reactions in Organic Synthesis; Oxford University Press, Inc.: New York, 2003; pp 181-184.

44. Cepanec, I.; Litvić, M.; Filipan-Litvić, M.; Grüngold, I. Tetrahedron 2007, 63, 11822. http://dx.doi.org/10.1016/j.tet.2007.09.045 